\section{O-373 $\mathrm{PGE}_{1}$ テスト時の陵蕉海綿体内カテコールアミン} 東邦大学医学部泌尿器科学第一講座

永尾光一・野澤英雄・中居敏明・吉田 淳・松橋 求 石井延久。三浦一陽・白井將文

【目的】 $\mathrm{PGE}_{2}$ 注射後の陰茥硬度は、AVSS と manual stimulation (MS の同時負荷により最大となり、ストレス負荷で抑制される。そして、 $\mathrm{PGE}_{1}$ に $\alpha$ ーブロッカーを加え注射するとストレスによる㧕制をある程度予防で きる。そこで今回ストレス負荷によりカテコールアミンがどのように変化 するか調査した。【対象㧍よび方法】東邦大学大森病院りプロダクション センターを訪れたインポテンス患者でPGE テスト時に振動覚測定という ストレス負荷で陰茎硬度の抑制が強かった应例で、 dynamic infusion

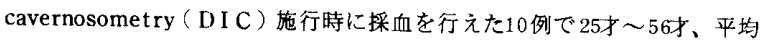
32.8 才であった。方法は、PGE $20 \mu \mathrm{g}$ を䧔茥海綿体に注射し、AVSS とMSの同時負荷を行い，勃起状態が安定したところで陰茎海綿体と时静 脈に $19 \mathrm{G}$ の翼状針を刺入する。針刺入痛というストレス負荷で陰茎硬度 が抑制されたことを確認し陰茥海䄸体と肘静脈の採血を行ない翼状針は留 置しておいた。つぎにAVSS とMSの同時負荷を再開し、再び勃起してい る状態で同様の採血を行った。採血終了後、DICを施行した。【結果】陰 译のノルアドレナリンは勃起抑制時 $0.203 \pm 0.0621 \mathrm{ng} / \mathrm{ml}$ 、勃起時 0.149 $\pm 0.0348 \mathrm{ng} / \mathrm{ml}$ と勃起抑制時に有意に高かった。时静脈のノルアト゚レナリ ンは勃起抑制時と勃起時に有意差は見られなかった。勃起抑制時と勃起時 をまとめると陰菜 $0.176 \pm 0.0571 \mathrm{ng} / \mathrm{ml}$ 、肘静脈 $0.237 \pm 0.0413 \mathrm{ng} / \mathrm{ml}$ で肘静脈が有意に高かった。アドレナリンとドーパミンはいずれも有意な 变化柱見られなかった。DICは、いずれも正常であった。【考察】陰茥の ノルアト゚レナリンは勃起抑制時に有意に高くストレス負荷時にノルフトレ ナリンを介して勃起が抑制されるものと考えられた。陰荎と时静脈の比較 で时静脈の方が有意に高かいことより陰茎以外から出るノルアドレナリン の関与も考えられる。勃起の抑制の強い思者でも最大陰菨硬度が正常であ れば陰䔄海綿体静脈閍鎖機能や海綿体動脈は正常である可能性が示唆され た。

\section{O-375動脈性インポテンスに対する血行再建術}

札幌医大泌尿器科

佐藤嘉一・高木誠次 ·堀田浩貴 $\cdot$ 鈴木一弘 - 塚本泰司

【目的】わが国においては動脈性インポテンスに対す る血行再建術の報告は少ない。両側の陰茎海綿体深動 脈の狭窄による動脈性インポテンスに対し血行再建術 を行ったので報告する。

【症例】症例は35歳、10年前よりインポテンスを認め ていた。Rigscanを用いた夜間睡眠時勃起現象測定では、 硬度の低下及び短時間の勃起しか認めていなかった。 PGE1テストではpoor responseであり、カラードプラ法 による㓌茎血流速度においても peak systric velocityが両 側の陰茎海綿体深動脈において低下が認められた。 のため動脈性インポテンスを疑い,動脈造影を行ったと ころ両側の陰茎海綿体媣動脈の数珠状の狭窄を認めた。 この狭窄による動脈性インポテンスと考えられたため、 血行再建術を行った。術式は下腹壁動脈及び陰茎背静 脈との吻合術を行う Furlow-Fisher法を行った。傍腹直 筋切開にて下腹壁動脈を確保し、陰茎背静脈と顕微鏡 下で端々吻合を行った。術後PGE1testにて完全勃起を 示すようになった。術後 2 週後より陰茎包皮に浮腫が出 現し、術後4週後より亀頭部にerosionが出現し、龟頭の 過血流状態と考えられ、再手術にて、陰茎背静脈の結 禁を行い、erosionは消失した。再手術後も PGE1testで は良好な反応性が継続していた。

【考案】血行再建術は年齢が若く外傷後等の単一の動 脈狭窄部位を有する症例に対しては有用である可能性 が高い。しかしながら亀頭へ流入する静脈の結紮は充 分注意すべき点と考えられた。

\section{O-374 神経障害症列のN P T 検討}

埼玉医科大学泌尿器科

永島弘登志・岩堀泰司・溝谷 学・浜田郁人・

四宮敏彦・宮川三樹夫・寺尾俊哉・岡田耕市

【目的】生理的正常な機能を有する男性は一晚に $3 \sim 5$ 回, 1 回25 35分間の夜間勃起現象をREM睡眠中に経験す るが神経障害例においてその障害部位によりどの様な NPT所見がみられるか，今回この点について検討した。

【対象・方法】対象は当専門外来を受診した上位中枢障 害 (頝髄障害 2 例)，下位中枢障害（DM性末梢神経障害 1 例, 骨盤骨折後の神経因性膀胱 2 例, 仙髄神経障害 1 例，骨盤内手術 4 例）において夜間睡眠時にRigiScan (DECOMED corp)によるNPTの測定を試み比較検討した。

【結果】膀胱癌, 直腸癌など根時的手術により骨盤内末 梢神経障害があるものはflat patternになる場合が多 い。またDM性末梢神経障害例においてはBaseは反応が あるがTipにおけるRigidityが0\%であった。また不完全 な頝髄障害例においてはBaseにおいては3. 40〜 $5.45 \mathrm{~cm}$, Rigidity75〜88\%,で約60分間隔程度で反応があるがTip においてRigiScan上硬度が出ない硬度不一致が認められ た。

【考察】膀胱癌 (術後), 直腸癌 (術後), DM性末梢神経 障害例など下位中枢障害で勃起に関する末梢神経がかな り障害されている場合flat patternになるものが多くみ られたが上位中枢障害(不完全な頝髄損傷)においては， dissociation patternが認められた。さらに症例を追加 して検討する。

\section{$0-376$ 静脈性インポテンス} 術後の再発に関する10年間の観察— 高松赤十字病院 川西泰夫，林秀樹，谷本修二， 小松歩, 大西智一郎, 山本 明, 沼田 明

【目的】勃起発現の際には陰荤からの血液の流出抵抗が上 昇する。この機能に異常があると勃起障害に陥るが，陰苦 外の静脈の結紮により治療される。この手術の問題点はそ の再発率の高いことであるといわれている，我々の施設で 陰䒚の静脈手術を施行した症例の再発の傾向について検討 した.

【対象】対象は過去10年間に静脈性インポテンスに対して 手術を行った123例である。全例とも海綿体㴶流検查によ り陰茎流出路の機能異常が診断された症例である，年齢は 24 から 77 歳, 平均 53 歳で, 術後の観察期間は 0.7 月から 120.5力月である。手術術式は深陰茥背静脈結禁術が74例, 陰茎海綿体脚部結紮術が24例，その他，25例であった。

【結果】短期成績では薬剂による勃起検查では110例，89\% が改善を示し，性交可能となった症例は69例，56\%であっ た． 3 年目の改善率は $67 \% ， 6$ 年目には $40 \%$ であった。再 発時期は 1 年末満， $1 \sim 3$ 年末満が多かった。術式による 再発傾向の差異は明らかではなかった．

【まとめ】10年間の観察により 3 年目までの再発が高頻度 でこの時期以降は勃起機能が維持される傾向にあった， 10 年目には約 3 分の 2 の症例で再発が認められた。 